\title{
Artemisia dracunculus Essential Oil Chemical composition and antioxidant properties
}

\author{
ARIADNA PETRONELA FILDAN ${ }^{1,2}$, IOAN PET ${ }^{3}$, DANIELA STOIN ${ }^{4}$, GABRIEL BUJ ANCA ${ }^{4}$, \\ ALEXANDRA TEODORA LUKINICH-GRUIA5, CALIN J IANU**, ADELINA MARIA JIANU6*, MATILDA RADULESCU, \\ DOINA ECATERINA TOFOLEAN ${ }^{1,7}$ \\ ${ }^{1}$ Ovidius University, Faculty of Medicine, 124 Mamaia Blvd., 900527, Constana, Romania \\ ${ }^{2}$ Constanta Clinical Pulmonology Hospital, 167 Alexandru Lapusneanu Blvd., 900001, Constanta, Romania \\ ${ }^{3}$ Banat's University of Agricultural Sciences and Veterinary Medicine King Michael I of Romania from Timisoara, Faculty of \\ Bioengineering of Animal Resources, 119 Calea Aradului, 300645, Timisoara, Romania \\ “Banat's University of Agricultural Sciences and Veterinary Medicine King Michael I of Romania from Timisoara, Faculty of Food \\ Engineering,119 Calea Aradului, 300645, Timisoara, Romania \\ ${ }^{5}$ OncoGen Centre, County Hospital Pius Branzeu, 156 Liviu Rebreanu Blvd., 300736, Timisoara, Romania \\ 'University of Medicine and Pharmacy Victor Babes, Faculty of Medicine, 2nd Eftimie Murgu Sq., 300041 Timisoara, Romania \\ ${ }^{7}$ County Clinical Emergency Hospital of Constanta, 145 Tomis Blvd., 900591, Constanta, Romania
}

Free radical scavenging activity, total phenolic content and the chemical composition of the essential oil isolated by steam distillation from Artemisia dracunculus $L$. was investigated. The isolation yield was $0.24 \%$ $(\mathrm{v} / \mathrm{w})$ based on the fresh plant material (leaves). GC-MS investigation identified 21 components, accounting 99.93\% of the total amount. The major components were sabinene (42.38\%), isoelemicin (12.91\%), methyl eugenol (9.09\%), elemicin (7.95\%) and beta-ocimene (6.46\%). The free radical scavenging activity of the essential oil of Artemisia dracunculus L. was evaluated in vitro by the DPPH assay (IC50 $=0.730 \pm 0.213$ $\mathrm{mg} / \mathrm{mL}), B H A$ and alpha-tocopherol were used as a positive control. The total phenolic content of the tarragon essential oil was evaluated by the Folin-Ciocalteu method (GAE $=0.451 \pm 0.001 \mathrm{mg} / \mathrm{g} \mathrm{sample).} \mathrm{In}$ view of these data, we consider that tarragon essential oil could represent a new antioxidants source as a reliable option to reduce the usage of synthetic additives.

Keywords: tarragon, essential oil, free radical scavenging activity, total phenolic content, antioxidant activity

The genus Artemisia part of the family Asteraceae (Compositae), consisting over 500 diverse species distributed principally in Europe, Asia and North America [1]. Artemisia dracunculus L. distribution spans over western North America, eastern and central Europe, and most of temperate Asia [2]. Tarragon (A. dracunculus) is a medicinal plant known and used in folk medicine from ancient times with anti-inflammatory, carminative, antiparasitic, digestive, antispasmodic, antiseptic, antipyretic and anthelmintic effects [1-3]. Also, tarragon has been used for flavoring foods. His pleasant, spicy aroma of the entire plant and its essential oil, represent the main reasons for the extensive use in the food industry $[2,3]$.

Tarragon essential oil is obtained from aerial parts of the plant during the flowering period [4]. The EO is a clear liquid, pale yellow to amber in color, with a delicate spicy odor; the extraction yield range between $0.15-3.1 \%$ [4-6]. Different studies have been carried out regarding phytochemical and biological activity of the tarragon EO. The main components of are methyl ethers, ocimene, myrcene, $\alpha$-pinene, $\beta$-pinene, camphene, limonene, and linalool [1, 3, 5-7].

Biological effects including antibacterial, antifungal and antioxidant activities have been previously reported for $A$. dracunculus. Tarragon EO demonstrated antibacterial activities over a vastspectrum, including human pathogens such as Pseudomonas aeruginosa, Escherichia coli, Staphylococcus aureus, Salmonella typhimurium and Staphylococcus epidermidis [8-10]. Also, the A. dracunculusEO has shown antifungal activity against some fungal species including Candida albicans, Cryptococcus neoformans, Aspergillus niger, Microsporum canis, Trichophyton rubrum, Microsporum gypseum and Fonsecaea pedrosol [8-12]. Additionally, A. dracunculus
EO and some of his components demonstrate, in vitro, a moderate radical scavenging activity [9-11].

Our study aimed to determine: i) the chemical composition and ii) radical scavenging activity and total phenolic content of the EO isolated from $A$. dracunculus leaves on which there are no previous studies.

\section{Experimental part}

Materials and methods

Reagents

2,2-diphenyl-1-picrylhydrazyl (DPPH); Folin Ciocalteu2 s phenol reagent (2N); anhydrous sodium sulfate; sodium carbonate; methanol; hexane (Sigma-Aldrich, Germany); butylated hydroxyanisole (BHA); alpha-tocopherol (Fluka Analytical).

\section{Raw material}

Plant material of $A$. dracunculus (Russian variety) was collected through the flowering period, in Ludestii de J OS,

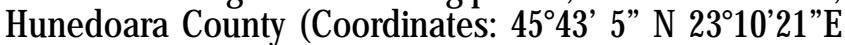
in August 2018. After the identification, a voucher specimen was deposited in the Herbarium of the Faculty of Agronomy, Banat's University of Agricultural Sciences and Veterinary Medicine King Michael I of Romania from Timisoara. Only leaves, fresh material, was studied. The essential oil of $A$. dracunculus was isolated by steam distillation, according to the method previously described by jianu et al. [13]. The essential oil was separated by decantation, dried over anhydrous sodium sulfate and stored $\left(-18^{\circ} \mathrm{C}\right)$ in sealed amber vials.

\section{GC-MS analysis}

The essential oil sample was diluted 1:1000 in hexane before GC-MS injection and analyzed on an HP6890 Gas-

* email: calin.jianu@gmail.com ; adelina.jianu@gmail.com 
Chromatograph coupled with HP5973 Mass Spectrometer. One $\mu \mathrm{L}$ of sample was injected in the splitless mode on a capillary column, Br-5MS, 5\% Phenyl-arylene-95\% Dimethylpolysiloxane, $30 \mathrm{~m}$ length, $0.25 \mathrm{~mm}$ internal diameter, $0.25 \mu \mathrm{m}$ film thickness (Bruker). GC oven temperature programme run in a range of $50^{\circ} \mathrm{C}$ to $300^{\circ} \mathrm{C}$ with $6^{\circ} \mathrm{C} / \mathrm{min}$, with $5 \mathrm{~min}$ last hold and a solvent delay of 3 min. MS source was set at $230^{\circ} \mathrm{C}$, MS Quad was set at $150^{\circ} \mathrm{C}$, and ionization energy was $70 \mathrm{eV}$. The gas flow which leads the sample through the column was helium at a flow rate of $1 \mathrm{~mL} / \mathrm{min}$. The weight range of scanned compounds was between 50 to 550 amu. All compounds found were evaluated based on their spectra compared to the mass spectrum from NIST0.2 library (USA National Institute of Science and Technology software), area percent was established. A semiquantitation based on the retention times by calculating Kovats indexes and a comparison to the Adams Indexes [14] from literature data was made.

\section{Free Radical Scavenging Activity}

The essential oil was analyzed regarding free radical scavenging activity by a Brand-Williams' adapted method [15]. $0.1 \mathrm{~mL}$ sample methanolic solution of the essential oil at different concentrations ranging from $1.5 \mathrm{mg} / \mathrm{mL}$ to $0.93 \mu \mathrm{g} / \mathrm{mL} / \mathrm{mL}$ was placed in Corning 96 Flat Bottom clear Polystyrol well plates. $0.1 \mathrm{~mL}$ methanol was used as the control of DPPH. All samples were diluted in a ratio of 1:10 (v/v) DPPH/samples and incubated at room temperature for $30 \mathrm{~min}$, in darkness. The absorbance was measured at $515 \mathrm{~nm}$ with a Tecan i-control, 1.10.4.0 infinite 200Pro spectrophotometer. The antioxidant activity was estimated by the inhibition percent of the DPPH free radical and calculated after the following formula:

$$
1 \%=\left(A_{\text {blank }}-A_{\text {sample }} / A_{\text {blank }}\right) \cdot 100
$$

where: $A_{\text {blank }}$ express the absorbance of the control, and $A_{\text {sample }}$ express the absorbance of the test sample.

IC50 was obtained using the BioDataFit 1.02 software (Chang Broscience Inc, Castro Valley, CA, USA). Each test was performed in triplicate.

\section{Determination of Total Phenolics}

The amount of total phenolic content was determined according to the Folin-Ciocalteu method, adapted from Swain and Hillis [16]. $15 \mathrm{mg}$ sample was weighted and dissolved in $1 \mathrm{~mL}$ methanol. A ratio of 1:5 sample and Folin-Ciocalteu reagent (diluted 1:10 in distilled water) was made and left for $5 \mathrm{~min}$ in the dark at room temperature; after this reaction an equal volume with Folin-Ciocalteu reagent of $7.5 \%$ sodium carbonate solution was added, vortexed, and left one hour at room temperature, in darkness. The absorbance was measured at $725 \mathrm{~nm}$ with a spectrophotometer Tecan i-control, 1.10.4.0 infinite 200Pro spectrophotometer. The total phenolic content was expressed in gallic acid equivalents (mg GAE/g sample) after a propyl gallate calibration curve was made with concentrations ranging between $0.375 \mathrm{mg} / \mathrm{mL}$ to 0.732 $\mu \mathrm{g} / \mathrm{mL}$.

\section{Results and discussions}

Hydrodistillation of $A$. dracunculus yielded $0.24 \%(\mathrm{v} / \mathrm{w})$ of essential oil, based on the fresh plantmaterial. Previously Arabhosseini et al. [17] report an amount of $0.6 \%$ essential oil in the fresh leaves of $A$. dracunculus (a Russian variety). Twenty-one volatile compounds were identified by their
Table 1

THE CHEMICAL COMPOSITION OF THE ESSENTIAL OIL EXTRACTED FROM LEAVES OF $A$. dracunculus CULTIVATED IN WESTERN ROMANIA

\begin{tabular}{|c|l|c|c|}
\hline No & \multicolumn{1}{|c|}{ Identification } & KI $^{\mathbf{a}}$ & Area (\%) $^{\mathbf{b}}$ \\
\hline 1 & alpha -Thujene & 911 & 0.27 \\
\hline 2 & alpha -Pinene & 917 & 0.51 \\
\hline 3 & Sabinene & 955 & $\mathbf{4 2 . 3 8}$ \\
\hline 5 & beta -Pinene & 959 & 0.43 \\
\hline 6 & beta-Myrcene & 969 & 1.74 \\
\hline 7 & alpha-Phellandrene & 986 & 0.19 \\
\hline 8 & alpha -Terpinene & 997 & 0.78 \\
\hline 9 & beta -Terpinyl acetate & 1010 & 0.9 \\
\hline 10 & (Z)-beta-Ocimene & 1017 & 4.78 \\
\hline 11 & g)-beta-Ocimene & 1028 & $\mathbf{6 . 4 6}$ \\
\hline 12 & Terpinolene & 1041 & 1.17 \\
\hline 13 & Terpinene-4-ol & 1071 & 3.28 \\
\hline 14 & Estragole (methylchavicol) & 1197 & 0.65 \\
\hline 15 & Citronellol acetate & 1364 & 2.06 \\
\hline 16 & Geraniol acetate & 1394 & 0.78 \\
\hline 17 & Methyl eugenol & 1418 & $\mathbf{9 . 0 9}$ \\
\hline 18 & beta-Cubebene & 1501 & 0.6 \\
\hline 19 & Isoeugenol methyl ether & 1515 & 2.61 \\
\hline 20 & Elemicin & 1566 & $\mathbf{7 . 9 5}$ \\
\hline 21 & Isoelemicin & 1660 & $\mathbf{1 2 . 9 1}$ \\
\hline & & Total: & $\mathbf{9 9 . 9 3}$ \\
\hline $\mathbf{y}$ & & 1178 & 0.39 \\
\hline
\end{tabular}

${ }^{1}$ Kovats indexes relative to n-alkanes on Br-5MS capillary column;

${ }^{b}$ percentages established by FID peak area normalization.

mass spectra characteristics and retention indices using a Br-5MS capillary column. The percentage of each compound and their retention indices were presented in table 1 . The major compounds were sabinene $(42.38 \%)$, isoelemicin (12.91\%), methyl eugenol (9.09\%), elemicin $(7.95 \%)$ and beta-ocimene $(6.46 \%)$. The EO is also contained (Z)-beta-ocimene (4.78\%) and terpinolene (3.28\%).

Arabhosseini et al. [17] investigating the chemical composition of essential oil from Russian tarragon leaves cultivated in the Netherlands report the presences of sabinene (39.4\%), methyl eugenol (14.7\%), elemicin (16 $\%)$, isoelemicin (7.7\%), (Z)-beta-ocimene (4.1\%) and (E)beta-ocimene (3.1\%) as the main components. Werker et al. [18] report that essential oil from Russian tarragon leaves mainly contained elemicin (36.2\%), sabinene (33.0\%) and methyl eugenol (7.1\%). These differences on the chemical compositions of the $A$. dracunculus essential oil can be partially attributable to environmental conditions $[2,17,18]$ and other factors such as genotypes and ontogeny $[2,5,19]$.

The free radical scavenging activity of the essential oil of $A$. dracunculus was evaluated in vitro by the DPPH assay (table 2). The tarragon essential oil demonstrated a low radical scavenging activity compared with $\mathrm{BHA}$ and alphatocopherol the positive controls used (Table 2). Our results comply with previous studies that also reported a weak DPPH radical scavenging activities for the $A$. dracunculus essential oils $[9,10]$. In contrast, the $A$. dracunculus extracts evaluated in previous studies demonstrate a higher free radical scavenging activity [20,21]. Natural extracts, including essential oils, are very complex mixtures of many different compounds with distinct polarity as well as antioxidantand prooxidant properties, sometimes showing 


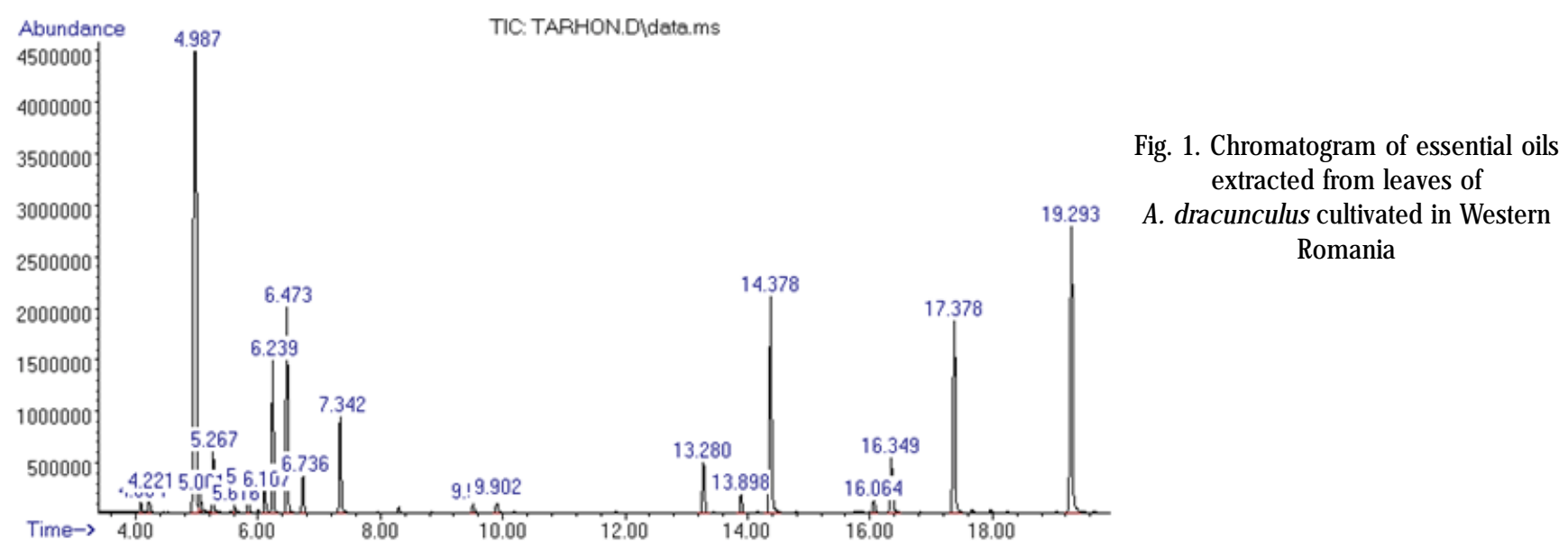

Table 2

YIELD, TOTAL PHENOLIC CONTENT AND DPPH RADICAL SCAVENGING ACTIVITIES OF THE ESSENTIAL OIL EXTRACTED FROM LEAVES OF $A$. dracunculus CULTIVATED IN WESTERN ROMANIA.

\begin{tabular}{|c|c|c|c|}
\hline Parameter & Essential oil & BHA $^{2}$ & alpha - tocopherol \\
\hline Yield (\%) & 0.24 & - & - \\
\hline DPPH, IC 50 (mg/mL) & $0.730 \pm 0.213$ & $0.0075 \pm 0.0001$ & $0.024 \pm 0.002$ \\
\hline Total Phenolic Content, (mg GAEb/g) & $0.451 \pm 0.001$ & - & - \\
\hline
\end{tabular}

"BHA - butylated hydroxyanisole; "GAE - gallic acid equivalent;

synergic actions by comparison with individual compounds [22]. Previously reports have demonstrated a linear correlation between total phenolic content and antioxidant activity in plants [20, 23-25]. This assumption is in accord with our results, the essential oil analyzed by us show ed a low total phenol content ( $0.451 \mathrm{mg}$ gallic acid / g sample). However, numerous compounds of different polarity, present in small amounts in the essential oils composition, can also contribute to the antioxidant activity. Hydrolysis and other separating methods are responsible for separating this compounds from the plant material. Additionally, the separating conditions (heat, extraction systems, etc.) can modify the biological properties of these natural extracts consisting of various compounds with different chemical and physical properties [26]. Future investigations are required to clarify the association between antioxidant activity and chemical composition of essential oils.

\section{Conclusions}

Summarizing the results, we conclude that the essential oil isolated by steam distillation from $A$. dracunculus $L$. leaves are rich in sabinene (42.38\%), isoelemicin (12.91\%), methyl eugenol (9.09\%), elemicin (7.95\%) and betaocimene $(6.46 \%)$. Also, the tarragon essential oil demonstrate antioxidant activity; besides, his scavenging activity is lower in comparison to BHA and al pha-tocopherol the positive controls used. In view of these data, we consider that tarragon essential oil could represent a new antioxidants source as a reliable option to reduce the usage of synthetic additives.

\section{References}

1.BORA, K.S., SHARMA, A., Pharm Biol, 49, 1, 2011. p. 101-9. 2.EISENMAN, S.W., STRUWE, L., Genet Resour Crop Evol, 58, 8, 2011. p. 1199-1212.
3.HASSANZADEH, M.K., TAYARANI NAJ ARAN, Z., NASERY, M., EMAMI, S.A., Chapter 92 - Tarragon (Artemisia dracunculus L.) Oils, In Essential Oils in Food Preservation, Flavor and Safety, ed. Academic Press: San Diego. 2016 p. 813-817.

4.ELIU-CEAUSESCU, V., RADOIAS, GH., CADARIU, T., Odorante si aromatizante chimie, tehnologie, aplicatii, ed. Bucharest: Tehnic Publishing House. 1988. p. 201-202.

5.OBOLSKIY, D., PISCHEL, I., FEISTEL, B., GLOTOV, N. , HEINRICH, M., J Agric Food Chem, 59, 21, 2011. p. 11367-84.

6.DEANS, S.G., SIMPSON, E.J.M., HERBS | Herbs of the Compositae, In Encyclopedia of Food Sciences and Nutrition (Second Edition), ed. Academic Press: Oxford. 2003 p. 3077-3081.

7.ABAD, M.J ., BEDOYA, L.M., APAZA, L., BERMEJ 0, P., Molecules, 17, 3, 2012. p. 2542-66.

8.BENLI, M., KAYA, I., YIGIT, N., Cell Biochem Funct, 25, 6, 2007. p. 681-6.

9.KORDALI, S., KOTAN, R., MAVI, A., CAKIR, A., ALA, A., YILDIRIM, A., J Agric Food Chem, 53, 24, 2005. p. 9452-8.

10.LOPES-LUTZ, D., ALVIANO, D.S., ALVIANO, C.S., KOLODZIEJCZYK, P.P., Phytochemistry, 69, 8, 2008. p. 1732-8.

11.TEIXEIRA, B., MARQUES, A., RAMOS, C., NENG, N.R., NOGUEIRA, J.M.F., SARAIVA, J.A., NUNES, M.L., Ind Crops Prod, 43, 2013. p. 587595.

12.MEEPAGALA, K.M., STURTZ, G., WEDGE, D.E., J Agric Food Chem, 50, 24, 2002. p. 6989-92.

13.JIANU, C., GOLET, I., MISCA, C., JIANU, A.M., POP, G., GRUIA, A.T., Rev. Chim.(Bucharest), 67, no. 6, 2016. p. 1056-1061.

14.ADAMS, R.P., Identification of Essential Oil Components By Gas Chromatography/Mass Spectrometry, ed.: Allured Publishing Corporation. 2007.

15.BRANDWILLIAMS, W., CUVELIER, M.E., BERSET, C., Food Sci. Technol.-Lebensm.-Wiss. Technol., 28, 1, 1995. p. 25-30.

16.SWAIN, T. , HILLIS, W., J. Sci. Food Agric., 10, 1, 1959. p. 63-68.

17.ARABHOSSEINI, A., PADHYE, S., VAN BEEK, T.A., VAN BOXTEL, A.J ., HUISMAN, W., POSTHUMUS, M.A., MÜLLER, J., J. Sci. Food Agric., 86, 15, 2006. p. 2543-2550. 
18.WERKER, E., PUTIEVSKY, E., RAVID, U., DUDAI, N., KATZIR, I., J Herbs Spices Med Plants, 2, 3, 1994. p. 19-32.

19.LIU, T., LIN, P., BAO, T., DING, Y., LHA, Q., NAN, P., HUANG, Y., GU, Z., ZHONG, Y., Ind Crops Prod, 125, 2018. p. 1-4.

20.MUMIVAND, H., BABALAR, M., TABRIZI, L., CRAKER, L.E., SHOKRPOUR, M., HADIAN, J., Hortic Environ Biotechnol, 58, 4, 2017. p. 414-422.

21.PAREJ O, I., VILADOMAT, F., BASTIDA, J., ROSAS-ROMERO, A., FLERLAGE, N., BURILLO, J., CODINA, C., J. Agric. Food Chem., 50, 23, 2002. p. 6882-6890.
22.KAHKONEN, M.P., HOPIA, A.I. , HEINONEN, M., J . Agric. Food Chem., 49, 8, 2001. p. 4076-4082.

23.CHALESHTORI, R.S., ROKNI, N., RAZAVILAR, V., KOPAEI, M.R., Jundishapur J Microbiol, 6, 9, 2013.

24.PAWAR, N., PAI, S., NIMBALKAR, M., DIXIT, G., Food Chem., 126, 3, 2011. p. 1330-1336.

25.PIRBALOUTI, A.G., FIROZNEZHAD, M., CRAKER, L., AKBARZADEH, M., Rev. bras. farmacogn., 23, 6, 2013. p. 861-869.

26.SINGH, G., MAURYA, S., DE LAMPASONA, M., CATALAN, C., J. Food Sci., 70, 4, 2005. p. M208-M215.

Manuscript received: 15.09 .2018 